\title{
Analyzing How Millennial Generation Implement Pancasila Value in Modern Era
}

\author{
Dewita Untari Novianty ${ }^{1}$, Moses Glorino Rumambo Pandin ${ }^{2}$ \\ ${ }^{1}$ Faculty of Psychology, Airlangga University, Surabaya \\ ${ }^{2}$ Faculty of Humanities, Airlangga University, Surabaya \\ $\underline{{ }^{1} \text { dewita.untari.novianty-2020@ psikologi.unair.ac.id; }{ }^{2} \text { moses.glorino@ fib.unair.ac.id }}$
}

\begin{abstract}
Introduction: Industrial revolution 4.0 in the current era of globalization plays an active role in the modern era in Indonesia. The influence of increasingly advanced technology affects the millennial generation as the nation's next generation to make Pancasila the basis of the State or the foundation of a State. In addition, the millennial generation has begun to shift the guidelines of life from Pancasila so that the appreciation of Pancasila values is starting to disappear along with the development of the times and in line with the progress of Science and Technology (IPTEK). If this continues, then the values of Pancasila will be replaced by a new ideology that will cause behavioural changes in society. Purpose: this study aims to provide the proper application to millennial life using Pancasila values, knowing the behaviour of the millennial generation towards the implementation of Pancasila values, and making Pancasila a way of life. Methods: the method used in this research is Literature Review and takes sources from journals published in 2019 to 2021 related to the Pancasila theme and the millennial generation. Results: the study results show that with the existence of Pancasila as the ideology and principle of the State, it is expected to strengthen the attitude and nature of the community in accepting things outside the norms that exist in Indonesia. In addition, the younger generation is expected to be able to apply Pancasila values along with the development of science and technology in the modern era and current globalization. The research question is how to make the millennial generation implement Pancasila in life in the contemporary period and what solutions can continue to instil Pancasila values in the 4.0 industrial revolution. Recommendation: the conclusion drawn is that Pancasila can become a unifying tool for the nation if the current generation or millennial generation still desires to maintain its values, even though they are in a modern era and many influences from its outside cultures. Limitation: the limitation of this research is not getting all the data directly from the source. The researcher recommends using primary data for the following study to ensure its truth and accuracy better because the researcher directly obtains it.
\end{abstract}

Keywords: Pancasila, Millennial Generation, Modern Era.

\section{INTRODUCTION}

Pancasila in Indonesia is the fundamental ideology and foundation of the State. Pancasila comes from Sanskrit which means, five are five, and precepts are principles or principles. 
Pancasila reflects the nation's character seen from the position of Pancasila in Indonesia as a guideline, goal, and view of life. In addition, Pancasila can be a benchmark for good and bad things. (1) Millennials are those born between 1980 - 2000. Millennials tend to want something instant. The impact of this is to make the individual indifferent to others and think about himself compared to the surrounding environment so that the individual rarely socializes and prefers to depend on technology, especially in urban areas. In addition, along with how easy it is to access technology, in this modern era, it is easier for individuals to receive information from various social media without filtering whether the information is valid or not. This issue needs to be investigated further because the spread of hoaxes can weaken Pancasila. After all, it has succeeded in sending waves of hatred and triggering fights between people. In addition, it can threaten the integrity of the nation and state, especially hoax news concerning SARA and religious issues. (2)

The theory used as the basis for the discussion of this research uses a literature study or literature study and is obtained from sources in journals and articles; data obtained from various sources are recorded to strengthen the theoretical basis of the research. This study aims to reapply the values of Pancasila in today's millennial life, even in the modern era, find out the behaviour of the millennial generation towards the implementation of the values that exist in Pancasila, and make Pancasila a way of life. From the research objectives, the authors determine several research questions, namely: 1 . How does the millennial generation implement Pancasila in everyday life in the modern era and globalization; 2 . What solutions can be done to continue to instil Pancasila values in the era of industrial revolution 4.0?

\section{METHOD}

The research method used in this study uses the Literature Review method, or can also be called the literature study method. The researcher collected several references related to the theme of this research, namely Pancasila and the Millennial Generation, and then made a summary and analysis. In addition, the sources used must be relevant and proven valid as scientific sources such as journals and articles. (3). The purpose of choosing this method is that studies that have been studied previously will complement each other with a study that will be explored further. Thus, it can answer research questions better than a single study.

Researchers went through several stages to compile this research. The first stage is that researchers collect materials in journals obtained from Google Scholar with themes determined according to the essential criteria for selecting journals, namely by the provisions, Pancasila and Millennial Generation. In addition, researchers used secondary data types, namely by looking for journals published in 2019-2021 to include new journals and proven validity in the current modern era, also finding journals with the keywords Pancasila, the millennial generation, and the contemporary era. The second stage is the researcher reads the references that will be used and 
note the essential parts that will be the reference for doing this research. The last step is the researcher makes conclusions from the notes that have been written previously. The first data analysis technique used is the content analysis technique, namely by taking the essence of various journals and references determined to produce conclusions following the research theme. The second data analysis technique is descriptive, namely by describing the data that has been found, so that the data can be used to answer the problems and research material, namely how generations implement Pancasila in the modern era. (3)

\section{RESULTS}

From all the references that I analyzed and the results of the literature review obtained from Google Scholar are as follows:

1. The article with the title "Pancasila Education for Millennial Generation" motivated by Pancasila is the State's ideology. It overcomes the notions of class, race, ethnicity, and religion. Pancasila was agreed upon by The Founding Fathers in 1945. The motto "Bhineka Tunggal Ika" is applied as a unified whole to place the interests of the Indonesian nation and state above other interests. The inculcation of Pancasila values for the younger generation cannot be done by coercion first, but with an approach through chat that seeks to understand the inner atmosphere of children today. The inculcation of Pancasila values in the younger generation must be inserted hoping that Pancasila can help us achieve progress and achievements to achieve happiness. (4)

2. The article with the title "Pancasila Perspective in Millennial Generation" is motivated by the value of cooperation in Indonesia which is fading in globalization. Furthermore, many influences from Western nations entered, such as dressing immodestly to mimic Western culture, being more selfish, a lack of courtesy to parents, or a lack of empathy for those in need. (2)

3. The article with the title "Practicing Pancasila Values for Millennial Generation" is motivated by Pancasila as the rules and basis for any norms that apply in Indonesia. All existing regulations must be sourced from Pancasila and are expected to become guidelines and views of the Indonesian people's life. Based on the structuralfunctionalism perspective, a pluralistic country like Indonesia needs values that can be used as binding values, meeting points, and national identity. Several figures expressed their opinion on Pancasila, the first being the first president of Indonesia, Ir. Soekarno; he said that Pancasila is the content of the soul of the Indonesian nation, which has been hidden from generation to generation by western culture. The second, Moh. Yamin said that Pancasila is the five basics that contain guidelines or rules of essential and good behaviour. The third, Notonegoro, Pancasila, is expected to be a view of life as a unitary unit. (5) 
4. The article with the title "Triggers for the Disappearance of Pancasila Values in the Millennial Generation" is motivated by Pancasila education, an important thing to be internalized into learning in schools and universities. Most importantly, Pancasila education must be taught from an early age. Children tend to it is easier to remember the basic lessons taught when they were small, and must be accustomed from childhood so that when they grow up, the basics of Pancasila can be applied in everyday life. Pancasila education in higher education can help students strengthen their knowledge of Pancasila. They can be responsible, obey the applicable regulations as stipulated, and resolve conflicts democratically, not through violence and judging others. (10)

5. The article with the title "Implementation of Pancasila Values Through Education for Millennial Generation" is motivated by the importance of Pancasila education taught from an early age. Thus, it is hoped that the millennial generation can understand that all activities must follow applicable norms and rules and apply the values in Pancasila in everyday life. (1)

6. The article with the title "Millennials Implementing Pancasila Values: A Hope and Aspiration" is motivated by the globalization era and currently entering the industrial revolution 4.0, demanding that humans enter into technological developments and has become a necessity for every young generation. Because of the easy access to technology, this generation tends to prefer instant things without being concerned with the process and more focused on the results obtained. In addition to advancing science and technology, not to bring the far away, sometimes technology even distances the near. Almost all young people have their means of communication. The behaviour of the millennial generation is not appropriate if it is applied to Pancasila values. For example, the principle of "Just and Civilized Humanity", even though they are gathered together, their hands and eyes only focus on the gadgets they use, so they tend to show an individualistic and unsocial attitude. In addition, the millennial generation is easily influenced by hoax news on social media because of the easy access to information. Not a few people continue the hoax news and disseminate it without knowing the truth and what the contents of the news are. Suppose every young generation has a personality filled with Pancasila values and has a strong character and soul. In that case, the younger generation will be formed into a bright generation, patriotic spirit, respect each other, and live in peace. It is created starting from individuals and families, continuing in a good society or environment. With education, the knowledge possessed is an embodiment. The millennial generation is the next generation of the nation who will later print civilization. (9)

7. The article with the title "Implementation of Pancasila Values for Millennial Generation in the Modern Era" is motivated by the need for reaffirmation because many have 
misunderstood Pancasila. They consider Pancasila as a tool of power that can control the Indonesian state, not only as of the basis of the state. (7)

8. The article with the title "Implementation of Pancasila Values as Guidelines for Millennial Generation in Behaving in Social Media" is motivated by the millennial generation as the most social media users in Indonesia. They have not implemented Pancasila in their activities on social media. Technology, information, and communication are developing rapidly in Indonesia today. Efforts that can be made to have awareness about the importance of practising Pancasila are through Pancasila education and increase the sense of love for the homeland and nationalism within oneself. (8)

9. The article with the title "Implementation of Pancasila Values Among Millennial Generations to Protect Yourself From the Negative Impacts of the Industrial Revolution 4.0" is motivated by the hope that Pancasila can become a unifying tool for the Indonesian nation. Industrial revolution 4.0 in Indonesia will automatically impact individuals because it affects their ethics, morals, and character. (6)

10. The article with the title "Research Methods in Religious Scientific Manuscripts" is motivated by a scientific journal written with an IMRaD (Introduction, Methods, Result, and Discussion) structure that always explains the method after the introduction. Company writing is essential before a writer reports the research results and discusses them in the analysis paragraphs. Research that wants to be the goal or research problem for which the answer is found. (3)

\section{DISCUSSION}

Pancasila values need to be applied to a just, prosperous, and harmonious society in carrying out daily life. Pancasila has an important role and position, especially for the sustainability of the Indonesian government; for example, Pancasila is used as an essential reference for making regulations. Thus, if the younger generation cannot instil the fundamental values of Pancasila as an ideology, it will be difficult to follow the applicable laws because all the rules are based on Pancasila. In addition, the planting of Pancasila values is an urgency; there are many ways that millennials can do that are close to technology. Life in the era of globalization makes individuals very easily influenced by things. Internet dependence is caused by the ease of finding information and the speed of access favoured by the millennial generation because this generation tends to prefer something instant. (8) 


\section{CONCLUSION}

Along with the development of science and technology in Indonesia, which is increasingly advanced and modern, it causes the value of nationalism and patriotism to fade, especially the younger generation. Therefore, Pancasila education is an important thing to be internalized into learning in schools, universities. Most importantly, Pancasila education must be taught from an early age. Children tend to be easier to remember the basic lessons taught when they were small and must be familiarized from childhood to adulthood; later, the basics of Pancasila can be applied in everyday life. Pancasila education in higher education can strengthen students' knowledge of Pancasila to be responsible, obey the applicable regulations as stipulated, and resolve conflicts between individuals and between groups democratically, not through violence and judging others. (7)

Millennials dominate the use of social media in Indonesia. Unfortunately, as the most social media users in Indonesia, the millennial generation has not implemented Pancasila in their activities on social media. According to the results of a survey from Microsoft, which shows that there are still many hoaxes, hatred, and discrimination on Indonesian social media that can threaten national unity. Pancasila is a noble value; values should be practised daily, including in cyberspace, to maintain national unity and state identity. The Indonesian people have Pancasila as an ethical guide in social media. Efforts that can be made to have awareness about the importance of practising Pancasila are through Pancasila education, increasing love for the homeland and nationalism within, creating a family environment that exemplifies Pancasila values, and using social media forums the importance of implementing Pancasila in life. (10)

The way to apply Pancasila as a way of life for the nation and state is to use Pancasila to carry out daily life because the values contained in Pancasila are the key to regulating attitudes and behaviour. Indonesian people must be able to appreciate and practice the truth values contained therein. If the truth value is not put into practice, then the philosophy of Pancasila as the nation's ideology will no longer have any benefits. The planting of Pancasila values for the younger generation cannot be done by coercion first. The way that is considered quite effective is by using a chat approach that seeks to understand the spiritual atmosphere of young people today. The inculcation of Pancasila values in the younger generation must be inserted hoping that Pancasila can help us achieve progress and achievements to achieve happiness. The delivery used must be attractive to motivate and mobilize the volunteerism of the younger generation in developing their potential. The delivery of Pancasila values can be done by packaging them in an exciting activity. Various ways can be done, including by doing intelligence through music, sports, arts, and self-defence that can be adapted to their respective disciplines. This activity is carried out so that the younger generation feels comfortable and the values they want to achieve can be easily embedded in their souls. The socialization of Pancasila values also cannot be determined by the time of making the material. If the delivery is not attractive, it will make the younger generation feel bored and create hatred. (1) 


\section{REFERENCES}

1. Sa'aadah SSDAD. Implementasi Nilai Pancasila Melalui Pendidikan Bagi Generasi Milenial. Konstruksi Sosial: Jurnal Peneliti Ilmu Sosial. 2021 November; 1(11).

2. Wulan SIA. Cara Pandang Pancasila Dalam Generasi Milenial. 2019 November; 1.

3.Zaluchu SE. Jurnal Teologi Berita Hidup. Metode Penelitian di dalam Manuskrip Jurnal Ilmiah Keagamaan. 2021 Maret; 3(2).

4. Hanum FF. Pendidikan Pancasila Bagi Generasi Milenial. 2019 Oktober.

5. Anggraini D. Pengamalan Nilai-Nilai Pancasila Bagi Generasi Milenial. 2019 November; 2(1).

6. Hasanah U. Implementasi Nilai-Nilai Pancasila Di Kalangan Generasi Millenial Untuk Membendung Diri Dari Dampak Negatif Revolusi Industri 4.0. 2021 Januari; 3.

7. Devyanne Oktari DAD. Devyanne Oktari, Dinie Anggraeni Dewi. 2021 April; 6(1).

8. Dinda Rahma DAD. Milenial Mengimplementasikan Nilai Pancasila: Sebuah Harapan Dan Cita-Cita. 2021; 3(1).

9. Angel Dwi Septianingrum DAD. Implementasi Nilai Pancasila pada Generasi Milenial di Era Serba Modern. 2021; 3(1).

10. Andriani Safitri DAD. Implementasi Nilai-Nilai Pancasila sebagai Pedoman Generasi Milenial Dalam Bersikap di Media Sosial. 2021; 3(1). 